European journal of American studies

Special Issue: Spectacle and Spectatorship in American Culture

\title{
Cinemas and Spectators of International Development
}

\section{Molly Geidel}

\section{(2) OpenEdition \\ Journals}

Electronic version

URL: https://journals.openedition.org/ejas/15440

DOI: $10.4000 /$ ejas. 15440

ISSN: 1991-9336

Publisher

European Association for American Studies

\section{Electronic reference}

Molly Geidel, "Cinemas and Spectators of International Development", European journal of American studies [Online], 14-4 | 2019, Online since 11 December 2019, connection on 08 July 2021. URL: http:// journals.openedition.org/ejas/15440 ; DOI: https://doi.org/10.4000/ejas.15440

This text was automatically generated on 8 July 2021.

Creative Commons License 


\title{
Cinemas and Spectators of International Development
}

\author{
Molly Geidel
}

1 The Forgotten Village, a 1941 documentary written and produced by John Steinbeck, contains a curious scene, a film-within-a-film that predicts and elucidates the role of film propaganda in mid-century modernization and development ventures. Children in the fictional Mexican village of Santiago are falling ill from typhoid, and the townspeople have refused modern medicine, relying instead on the diabolical folk healer Trini to cure them. After a few children have died, enterprising teenager Juan Diego undertakes a new strategy: he will show the town an educational film in the village schoolhouse. Over the mournful sounds of townspeople praying outside, Juan Diego reverently unspools a film he has borrowed, with the help of a sympathetic teacher, "from the federal school of the neighboring market town." The voiceover, by character actor Burgess Meredith, intones about the educational film, "It was a strange and wonderful object to them, and they planned to show the people of Santiago what caused the sickness, and how the children could be cured." In a scene that anticipates many development films produced by US artists and planning agencies in subsequent decades, Juan Diego and his teacher talk animatedly but inaudibly, their faces beautifully lit, their democratic impulses drowned out and summarized by the imposing voiceover. "They wrote a petition to the medical authorities in the distant capital," Meredith explains.

In its first moments, the screening seems successful: the camera pans over the reverent faces of the townspeople, then lingers on Juan Diego's hopeful expression. But as the screen shows a close-up of a horse, with Meredith explaining, "Serum from an infected horse can cure the children," a man in the audience-"the landowner"-springs from his seat, breaking through the reveries of the viewers around him. "Horses' blood!" Meredith ventriloquizes. "Are we animals?" The teacher implores the townspeople to stay-"The men of science work to help you"-but to no avail. The villagers rise up together to chastise Juan Diego and abandon the screening, loudly asserting that they "do not like new things." Next we cut to another shadowy interior where Trini is 
administering "a new cure" to Juan Diego's younger sister: she brandishes "a snakeskin, to draw the pain," and lays it over the child's stomach in a careful movement that mirrors the unspooling of the filmstrip in the previous scene. The community's stubborn rejection of modernity causes Juan Diego to leave Santiago, walking "into a new world" to find a doctor and bring him back to the community. However, this effort too is unsuccessful, and at the close of the film he leaves the village behind. As he is spirited away by the doctor, light shining on his face as he hurtles forward in the otherwise dark space of the car, the voiceover speaks to him, informing him that he is on a modernizing path like children all over Mexico, children who will lead their country on its "long climb out of the darkness." In the closing moments of the film, Meredith's voice declares, "I am Juan Diego" as the boy gazes rapturously up into the light.

In its formal elements as well as its way of seeing populations, The Forgotten Village marks the beginning of a new era in both international development and documentary film. While its designation of "the landowner" as the instigator of the revolt at the screening suggests that it takes up, however vaguely, the leftism of Steinbeck's prior work, gone is the ambivalence about technological progress that characterized much New Deal-era culture. ${ }^{1}$ Muted also is the salvage-ethnographic impulse of the early documentaries depicting rural indigenous people, films that attempted to preserve customs and cultures threatened by the encroachment of modernity: here, at least according to the voiceover and the narrative action, there is nothing worthwhile to preserve. ${ }^{2}$ Rather, in its representation of modernization and development as an all-ornothing social process that can occur only after the personal transformation of backward "villagers," the film presages the modernization theory created in the universities and think tanks of the 1950s United States. ${ }^{3}$ Its tropes, which become standard in the development film over the course of the next few decades, reflect this certainty: its lack of color and synced sound, invoking an earlier era of film; its hopelessly "traditional" inhabitants who, despite being played by amateur villageractors who have welcomed film crews into their village, stubbornly reject all things modern; its forward-looking men mutely yet animatedly articulating their civic vision; and the camera lingering on the face of a child (generally a boy, often at the close of the film), bathed in light, promising a better future and allowing audiences to share in it. ${ }^{4}$

Despite the hundreds of films like The Forgotten Village (and the educational film we glimpse within it) that were screened in classrooms, theaters, and mobile film units around the world in the 1940s, 1950s and 1960s, the role of film in international development is under-researched. While historians have meticulously traced the origins of postwar modernization schemes in Enlightenment intellectual traditions and anticolonial labor struggles, as well their crystallization in Cold War think tanks and universities, they have paid much less attention to the popular circulation of development images and ideas. ${ }^{5}$ Similarly, film scholars, while often adopting the broad category of modernity as a central framework for understanding film and its audiences, have been less inclined to study the history of film and its audiences in relation to development. ${ }^{6}$ While scholars have done excellent work on early imperial and corporate filmmaking by European powers and corporations, the mid-century development film in the Americas, which both inherits and revises those forms and practices, has received less attention. ${ }^{7}$ This article takes up the question of spectatorship in development films, asking what kind of spectators modernization theorists, filmmakers, state agencies and international organizations attempted to 
construct, where and how development films were screened, and what effects these films might have had on at least some of the diverse audiences who saw them. Studying spectatorship is complicated by the dual purpose of these educational films: they were meant to instruct "underdeveloped" communities, but they were also meant to induce "modern" spectators to understand and accept the modernization mission. The films, of course, did not always reach their intended audiences, and the two categories of imagined spectators, sharply distinguished from one another by the Manichean vision of development discourse, were often blurred in practice. In this article, I consider both the intended and the actual spectators of development films from the 1940s through the late 1960s, tracing how ideals and practices of spectatorship were connected to changing visions of development. First I focus on The Forgotten Village, tracing the way Steinbeck and director Herbert Kline crafted their film for mass audiences but ended up convincing mostly expert spectators of the documentary value of their story; then I move on to 1950s screenings of development films by the US Information Agency (USIA) and UNESCO, contrasting the negative responses of elite international test audiences with the more positive reactions from indigenous Mexican audiences in the interactive screenings held at UNESCO's site in Pátzcuaro, Mexico. Finally, I discuss the self-conscious treatment of spectatorship by USIA filmmaker James Blue, whose position on both development and spectatorship evolved significantly over the course of the 1960s.

\section{Creating the Spectators of Development}

5 Daniel Lerner is the modernization theorist who most forcefully equates modernization with proper spectatorship. In his 1958 book The Passing of Traditional Society, he posits that the key to modernization is the creation of the "mobile personality," the set of traits which facilitated the move in the West from "farms to flats and from fields to factories." worker, "distinguished by a high capacity for identification with new aspects of his environment," who "comes equipped with the mechanisms needed to incorporate new demands upon himself." This disciplining, Lerner argues, can happen much more rapidly with the help of mass media, which teaches audiences both an "expansion of psychic mobility" and an "inhibition of overt active response." By teaching this combination of imaginative identification and self-control, Lerner argues, mass media "have disciplined Western man in those empathic skills which spell modernity." ${ }^{10}$ For Lerner, identificatory spectatorship is the key mechanism that disciplines the viewer into a successful modern existence. In touting mass media as a mechanism for modernization, Lerner articulates the contradiction that is also seen over and over in development films: modernization requires and brings about a "participant society" in which the population must "have opinions on public matters" while at the same time submitting to a predictable trajectory in which they must relinquish control over the material circumstances of their existence. ${ }^{11}$ In this account, proper spectatorship, understood as an imagination that is at once expanded and confined by a scripted set of desires, both guides and is itself a key mode for the "developing" subject.

By 1959, Lerner's recommendations that the United States pour resources into cultivating this type of identificatory discipline in Third World subjects had gained widespread influence; he and his cohort spurred John F. Kennedy's massive investment 
in modernization and development in subsequent years. But Lerner and other theorists drew on a modernization imaginary that had been cultivated in the United States for years through development film narratives. In the 1940s, artists such as Steinbeck, whose New Deal-era images of stoic poverty had been instrumental in cultivating popular acceptance of a welfare state in America, began creating visual narratives of underdevelopment and its destruction that made the reductive taxonomies of modernization theory comprehensible. This time, of course, the ultimate goal of USsponsored modernization would be the creation of subjects completely in submission to the demands of global capitalism, forthrightly characterized by modernization theorist Walt Rostow as "an economic system whose methods are subject to regular change, and one which also confines the individual in large, disciplined organizations, allocating to him specialized, narrow, recurrent tasks." 12

Despite its lack of official backing, Forgotten Village is the World War II development film that resonates most strongly with later modernization theory and development policy. Determined to make a film that was useful to the war effort in the Americas, Steinbeck conceived of and controlled the project. ${ }^{13}$ Kline approached him with the idea of making a film about the Mexican Revolution, and Steinbeck agreed. In a letter to Kline in late April 1940, Steinbeck proposed that the film should be the story of three generations, of which "Grandpa was a peon on the hacienda, papa worked in an oil field, Juan Diego $3^{\text {rd }}$ is an ejidero." ${ }^{14}$ Already nudging Kline away from revolutionary politics and toward a narrative of scientific progress, Steinbeck suggests in that letter that "the story will be that of the process from hacienda to ejido, interrupted by a number of forces," such as "ignorance" and "disease." ${ }^{15}$ In the end, neither hacienda nor oilfield appears in Steinbeck's final script, and the ejido is not identified as such in either the script or the film; the entire backdrop of revolutionary Mexico has fallen away, restored only at the end of the film with the camera's brief yet reverent pans over children studying at new public schools.

Steinbeck's decision to focus on scientific progress in The Forgotten Village stemmed both from his disillusionment with "politics" after the success of Grapes of Wrath had made him an object of unwanted leftist attention and from his ever-intensifying desire to participate in the war effort in the Americas. While in Mexico scouting locations for his film, he worried about the contentiously fought upcoming election; he was particularly alarmed at what he perceived as widespread support for right-wing presidential candidate Juan Andreu Almazán and his possible fascist tendencies. ${ }^{16}$ Though Andreu Almazán ended up losing the election, Steinbeck was concerned enough that he wrote to Franklin Roosevelt in June 1940 to express his concerns and to propose the creation of a hemispheric propaganda office. ${ }^{17}$ Although Roosevelt did not take Steinbeck up on his offer to deploy his own "smoothly running movie crew" in the service of a propaganda operation, he did establish the office of the Coordinator of Interamerican Affairs, directed by oil heir Nelson Rockefeller, in August of that year. Steinbeck suggested to Kline that the office was a result of his entreaties, and the timing suggests that, at the very least, Steinbeck and Rockefeller had similar ideas about the importance of hemispheric propaganda. ${ }^{18}$

9 Steinbeck's preoccupation with wartime strategy and propaganda seems to have led him to simplify the story of his film. Kline remembered that Steinbeck wrote the script in Mexico in two weeks, and then left for California, leaving Kline to cast and shoot the film with the parting words of advice: "You must try to direct this, Herb, as I try to 
write-on one top level for our peers, those who know as much as we like to think we know-and on another level to keep it simple and true for people with little or no education so they can understand and be moved by our story." ${ }^{19}$ Kline got to work assembling his fictional family and directing them in difficult, intimate scenes, for example using method-acting coaching to get the women to enact a brutal "Aztec-style birthing scene" that had little to do with the realities of either Aztec or Mexican birthing practices. ${ }^{20}$

Thus, in order to resolve his worries about the direction of politics in Mexico, Steinbeck did not attempt to understand or depict those politics, but rather retreated from them. His commitment to working in a popularly accessible medium and form, and to uniting rather than dividing the hemisphere, seems to have compelled him to erase entirely from his film the contentious national politics he observed while scouting and the "political-minded people" Kline observed while shooting. ${ }^{21}$ Even though stills from the weeks of filming The Forgotten Village show raucous crowds filling the village's central plaza on election day, with some townspeople holding banners, demonstrating their political involvement and their efforts to display themselves as literate modern citizens, the film depicts the same village as quiet and insular, with no trace of the national identifications their real-life counterparts so ostentatiously exhibited. Steinbeck's solution to his wartime worries, then, seemed to be twofold: erasing political conflict from the picture altogether in favor of a simple evolutionary narrative, and combatting what he called the "emotional hysteria" of fascist and communist ideologies (here symbolized by Trini and her folk wisdom) with an unblinking faith in science. ${ }^{22}$

11 For Steinbeck, the imperative to create a compelling case against the folk irrationality he associated with fascism and communism led him to adopt melodramatic elements: he dramatized the conflict of "hysteria" versus science and rationality within a particular family along gendered lines. The opening intertitle of The Forgotten Village reads "This is the story of the boy Juan Diego, and of his people who live in the moment where the past slips reluctantly into the future." The community is situated in the past by the presence of the intertitle as well as its content, giving The Forgotten Village the feel of a silent film. The score, by leftist composer and Bertolt Brecht collaborator Hanns Eisler, and the lack of synced sound throughout, contribute to this sense that we are looking at the past. Through the film's tender, slow opening scenes the audience is drawn into the story of Juan Diego and his young mother, who gives birth to a beautiful baby with Trini's help, in the "Aztec-style" scene. It is only when the baby becomes sick that Trini is revealed as the evil embodiment of underdevelopment, the force that is infecting the village and keeping it from modern science and technology. Thus the "modern" spectator first becomes identified with Juan Diego's family, but is then encouraged to see them as Juan Diego begins to, as naïve victims tricked by Trini into slamming the door on the doctors who would save their children. This melodramatic scenario appears not only in the film's plot, but also in its lighting: Trini and the women who listen to her are repeatedly shown in shadowy darkness, while Juan Diego is bathed in light.

12 Steinbeck identified this infusion of family melodrama into the film, which otherwise resembled the films in the ethnographic tradition established by Robert and Frances Flaherty, as Forgotten Village's great innovation in relation to the documentary form. In 
the companion photo book to the film, he boasts of the film's intimate focus, confident that the family story will instill both knowledge and commitment in viewers:

A great many documentary films have used the generalized method, that is, the showing of a condition or an event as it affects a group of people. The audience can then have a personalized reaction from imagining one member of that group... In The Forgotten Village we reversed the usual process. Our story centered on one family in a small village. We wished our audience to know the family well, and incidentally to like it, as we did. Then, from association with this little personalized group, the larger conclusion concerning the racial group could be drawn with something like participation. ${ }^{23}$

Steinbeck's identification of the fictional family drama in his film as its real innovation helps us identify some of the new facets of international development thinking that became ubiquitous in the early Cold War era. Although Steinbeck writes of a "racial group" rather than of a culture, he otherwise perfectly articulates what would become the dominant discourse of the postwar world: when American audiences learn to "know" and "like" individual racialized Third World people (though not to respect their cultural practices), they will be compelled to make generalizations about them and at least imaginatively wish for their development in "something like participation." In other words, they are conscripted in what becomes the Cold War project of knowing the Third World through stereotypes and emotionally participating in its development. This drive to enlist American viewers' participation in development explains the "I am Juan Diego" scene at the film's end: it draws viewers into full, intimate identification with the rootless and modernizing Juan Diego, while Trini and the other villagers move further away from viewers' comprehension. The film thus creates a global community in which "developed" and "developing" spectators might intimately identify with one another (rather than, say, oppose one another in class struggle), and in which they might look with pity upon the underdeveloped.

The film's creation of the empathic and masterful spectator was successful, albeit with the limited audiences who saw it. Made by Steinbeck at the height of his fame, The Forgotten Village was reviewed widely and positively. Despite the film's melodramatic plot elements, reviewers mostly understood the film as a faithful document of Mexican village life, free of any artifice or shaping narrative. Philip K. Scheuer of the Los Angeles Times, for example, wrote authoritatively that "Winning over the suspicious populace was a task requiring infinite patience and sometimes guile, but once convinced the gringos meant no harm the Indians went about their business of living as if the camera wasn't there." ${ }^{44}$ The Forgotten Village also landed on several critics' "best of" lists for 1941, falling behind Citizen Kane but well ahead of Sullivan's Travels and The Maltese Falcon..$^{25}$ That the film was on multiple lists with these much better remembered films is remarkable, as is the contrast between them: the other three films, in different ways, are all inflected by the anti-capitalist sensibility of the Depression years, the general sense that some people are poor because others are rich. In blaming traditional folk culture and the overly powerful women who practice it for poverty and disease, Forgotten Village signals the amnesia that would characterize development thinking, the severing of poverty from politics in what James Ferguson has called the "anti-politics machine," and which Zoe Druick has identified in British films of the early 1950s. ${ }^{26}$

15 Social scientists likewise seemed impressed with the film. Anthropologist Robert Redfield, whose interwar studies of Mexico shaped postwar modernization theory, reviewed the film's accompanying photo book favorably for the American Sociological 
Review, pleased that "the presentation manages to treat the folk beliefs sympathetically and yet to be propaganda for science and progress. A work halfway between art and reporting, it is faithful to ethnological fact." ${ }^{27}$ Alvin Johnson, an economist and one of the founders of the New School for Social Research, wrote an indignant letter to the New York Times about the state's attempt to censor the film over its graphic birth scene (an attempt that was ultimately overruled by the Board of Regents after Eleanor Roosevelt intervened on the film's behalf), arguing that "the picture is a singularly complete and penetrating account of the whole life of a primitive community," while also marveling that "It is remarkable in these days of cynical depreciation of scientific progress to encounter a writer of the 'younger generation' who exhibits the intelligent zeal for scientific progress that made the Enlightenment the brightest page in modern history." ${ }^{28}$ Ironically, then, Forgotten Village had a very different career than Steinbeck had anticipated for it: although he and Kline had simplified the story for the sake of "people with little or no education" they imagined as their sole audience, the film never gained distribution in the United States or Mexico. Rather, it was seen and appreciated by a small but influential class of liberal intellectuals and social scientists, many of whom understood it as a faithful ethnographic document. Like the filmwithin-a-film, Forgotten Village seemed "wondrous" to the experts while failing to reach the masses of rural villagers.

While the film's melodramatic and exaggerated plot elements seem to have gone unnoticed by US reviewers and social scientists, there were a few mildly dissenting voices. Mexican Ambassador to the United States Francisco Castillo Nájera, in a letter to Hollywood executive Arthur Mayer, appreciated the film aesthetically, calling it "a masterpiece of art and of sympathetic understanding of the task which confronts the Mexican government in few of the very remote villages of my country." He continues: "I must say, nevertheless, that although its title brings out the fact that the environment which you represent in your film represents neither the normal nor the average social and sanitary conditions which prevail in most of our small communities, I am afraid that unintelligent audiences may derive that false impression...I fear that some of the public in this and other countries, prone to be indiscriminating, might get an erroneous impression of Mexico as a whole." ${ }^{29}$ But even Castillo Nájera's anxiety about spectatorship was not quite accurate: like Steinbeck, he worried most about "the public," missing the possibility that the "unintelligent audiences" would be US reviewers and social scientists, who used it to support their assertions about "The Generic Folk Culture of Mexico," as one Rural Sociology article put it. ${ }^{30}$

The film also traveled in development circles. It was adapted for Puerto Rico's pioneering development film division DIVEDCO, translated into Spanish as Pueblito de Santiago, and screened in US churches in preparation for missionary trips. ${ }^{31}$ It was also acquired in the early 1950s for the film library at CREFAL, an institute near the location of Forgotten Village's filming and one of the key UNESCO sites for its program of development through fundamental education, and particularly for the practice of adult education through interactive film screenings. ${ }^{32}$ CREFAL filmmakers seem to have mimicked sequences in Forgotten Village, though, as we shall see, they also amended key elements of the idea of the development spectator, attempting to preserve and celebrate distinct cultural heritages while also attempting to destroy aspects of these cultures to make way for modern values and practices. 


\section{CREFAL: Spectators Join the Parade}

18 Although film was a significant part of the US Information Agency (USIA)'s output from the moment of its 1953 founding, and Third World development imperatives shaped the agency's mission, the development film would not arrive at USIA until the Kennedy era. In the 1950s, USIA films bound for the Third World tended to be made for "significant audiences"-often military and police officers, teachers, students, and political officials -rather than focusing on the "politically inert" masses, as one report on USIA activities in Thailand called them, arguing that "showings to the masses should be deemphasized to a greater extent." ${ }^{33}$ Perhaps because of this imperative to screen development films for "leaders" rather than ordinary people, the 1950s USIA generally made and screened documentaries focusing on the United States, with sweeping stories rather than personal ones. Productivity: Key to Plenty (1949), one film that was screened throughout the 1950s, begins with the disclaimer that "This film presents one aspect of the economics of American life. It does not deal with the values of moral and spirit which give depth and meaning to man's existence..." Rather, the film uses animation and impersonal footage to pose and answer the question "Why is the American income so much higher than the others?," then swerves into a broad discussion of nineteenthcentury life that tells in broad strokes a triumphant story of US industrial development (neglecting, of course, to mention the role of slavery or even cotton production in generating this development).

19 Comments by test audiences on Productivity: Key to Plenty (1949) and the 1953 USIA film A Nation Sets its Course demonstrate the limits of this sweeping form for inspiring the model of spectatorship Lerner imagined. Productivity was reviewed by "a panel of ten nationals of foreign countries" that were classified as either "mainly" or "moderately" agrarian. Despite being composed of nine men and one woman, the panel reported "that the motion picture lacked feminine appeal, was too over simplified, [and] made mass production methods seem too mechanical and too unpleasant." ${ }^{34}$ Downplaying the general lack of enthusiasm from the respondents, the summary of the findings suggested that the film was too technical to "be understood by the average man abroad," and recommended that screeners "be very selective about the audiences who view this film; business groups, engineering students, and leaders probably may benefit the most from it." ${ }^{35}$

Likewise, in the test screening of A Nation Takes its Course, USIA officials explained their attempts to convince "fifteen foreign subjects, ten of them Asians," that "the young American nation [faced many] "problems like those their home countries now face." 36 Only two in the test-screening audience precisely grasped "the paramount objectives of the film," which were that "the history of the USA resembles, in a high degree, the history of every young nation trying to stand on its feet," and that "through hardships and problems only we can [i.e.: can we] gain freedom and democracy." In these and other instances, test audiences made up of "Third World nationals" critiqued both the style and the content of the films, suggesting some of the problems with USIA's 1950s strategy of influencing potential leaders with appealing images of US factory production and consumer culture. ${ }^{37}$

21 Mexico provided a key site for the emergence of a very different type of development film project than that at the USIA, one which more closely followed the path Steinbeck recommended in its attempts to convey the urgency of development through personal, 
melodramatic narrative. CREFAL (Regional Center for Fundamental Education for Latin America) was founded by UNESCO, in Pátzcuaro, as a site for training educators from throughout Latin America in both education and the production of audiovisual materials. Classes of "mid-level" development workers learned to make films and filmstrips on discrete health and agricultural topics and to show them at community forums. UNESCO's philosophy of fundamental education, a more humanistic iteration of the modernization theories formulated a decade later, was shaped by progressive educational thinkers of the interwar years, who imagined that education should facilitate world peace, and that educators should "develop the curriculum out of the materials of children's present social life." ${ }^{38}$ Upon the organization's founding in 1945, planners invited 14 experts who believed in progressive education, including Margaret Mead, to submit papers on the meaning of fundamental education. While there were similarities among the papers-most agreed on "fundamental education" rather than "mass education" as a key term, arguing that it encompassed both adult and childhood education, as well as differences among cultures. As Joseph Watras argues, the experts disagreed on the focus of Fundamental Education, and thus ended up confirming its status as a program "whose shape depended on the particular situations in the region it served." ${ }^{39}$ This commitment to situational specificity sat a bit uneasily alongside a more universalizing proposition to "help countries whose populations lived in poverty and ignorance." ${ }^{\prime 0}$ From approximately 1950 to 1961 , the years that CREFAL attempted to realize the fundamental education mission, it struggled to reconcile this commitment to local specificity with the universalizing imperatives of development.

Film, especially at CREFAL, was a key part of this fundamental education project. CREFAL employed educational experts to work on the production and attend the screenings of their films; they did not assume, as development organizations later would, that having made it satisfactorily to adulthood in a "modern" society qualified one to impart nebulous concepts such as "leadership" and "community building." ${ }^{41}$ In their statement of philosophy, CREFAL's trainers argued that audiovisual materials were key to instilling particular teachings, "based on the psychological fact that what one learns through sight and hearing is better understood and remembered that what is learned through other channels." They also argued that audiovisual materials had the power to create an emotional state that would make people more receptive to new ways of thinking, but that successful education would only be realized through constant interaction with the students and educators using those materials. ${ }^{42}$ This emphasis on interaction contravenes Lerner's model, in which becoming a modern spectator entails suppressing and intellectualizing one's reaction to a moving image.

Because of fundamental education's emphasis on situated contexts for learning, CREFAL officials assumed that the vast cultural, economic, and geographical differences between the rural communities they hoped to reach and the agricultural communities of the United States and Europe would make the importation and translation of USIA films difficult. Thus, they determined that Latin American filmmakers and educators would either have to make their own films or drastically adapt the materials they were given. ${ }^{43}$ CREFAL's staffers did use USIA films, which were circulating heavily throughout Mexico during the 1950s, as well as films from the Canadian Film Board and European film agencies, but only after educational staffers and students produced written evaluations of these films and their suitability for the local community. ${ }^{44}$ Staffers and students were asked in surveys whether each film was educational, good 
for adults, good for children, and "intelligible for the community," and whether it would benefit from further explication. ${ }^{45}$

When staffers' evaluations of the films were positive, filmmaking teams showed them to local communities, making changes to the films before further exhibition. ${ }^{46}$ In contextualizing the screenings as well as adapting them, CREFAL emphasized the "importance of two-way traffic between the materials-production centre on the one hand, and the village community on the other." ${ }^{\prime 7}$ In practice, this meant that instructional films underwent significant adaptation as educators attempted to modernize local populations. In a 1953 program of weekly screenings, for example, one of CREFAL's film students, J. Ernesto Rosales Urbino, showed three films, two USIA films made in Puerto Rico and one English film. For one of the Puerto Rican films, Desde las nubes (From the Clouds), despite its production by the similarly fundamental educationoriented DIVEDCO, CREFAL's film section wrote a script adapted to local farmers; Rosales noted that the new narration "perfectly fit the film." ${ }^{48}$

Film screenings in the communities around CREFAL were highly choreographed, multipart events. In the case of Rosales' 1953 screenings, he reported that the attendees included fifty to eighty local farmers, mestizos who spoke good Spanish, with "medium cultural preparation" and "good maturity of perception." He wrote that they were very enthusiastic about the films. Women and children, according to Rosales, also attended the screenings in great numbers; meanwhile, the men in these audiences outnumbered the 56 ejiditarios who lived in the community, suggesting that community members had brought their sons and other relatives who lived elsewhere. He also noted that, despite the agricultural content of the films, the women and children "conducted themselves very sensibly." Rosales prefaced the films with a motivational speech and stopped the film at important moments to emphasize the connection between their problems and the solutions depicted. He writes that one farmer said, "We too can do this, we just have to overcome our laziness, but if we make an effort, we'll have a better life!" The film was followed by a more extensive discussion, in which Rosales collected the farmers' impressions. He noted that the screenings had made the farmers enthusiastic about using herbicides, and that they would begin using new fertilizers in order to plant wheat and then rice in the plots where corn was now growing. He concluded that "presenting films with a well-designed, well-executed program can put farmers in the mood to think hard and act to improve their economic conditions through new modes of labor. If it doesn't require great sacrifice, they can be motivated to do it." 49

The principles of modernization and development Rosales emphasizes in his report seem familiar: the ranking of the community's "maturity of perception," the emphasis on motivation, accepting change, working harder, and technological fixes such as herbicides. However, the care with which the screening was planned suggests an attentiveness to local conditions that is lost in the universal propositions of modernization theory, as well as in later imaginings of development workers as interchangeable embodiments of modern values. Furthermore, Rosales' sunny platitudes about motivation are qualified by his caution about sacrifice, which is at odds with the later formulas of theorists such as Lerner and Rostow, who imagined that rapid development, although necessary, would exact a high price from "traditional" communities. The experiences of the adaption and screenings by CREFAL educators suggests a more interactive, locally situated and listening-focused mode for 
development than that which the United States and international organizations would pursue in the following decades.

One attempt to realize CREFAL's development ideals is the 1953 documentary Tzintzuntzan, which celebrates the inhabitants of the eponymous community while showcasing a development program that allows them to improve their techniques for weaving and making ceramics. After leading viewers through an arduous yet beautiful day in the life of Tzintzuntzan residents, explaining that they value community while questioning the efficiency of their fishing and food preparation practices, the narrator asks, "but what is the new element that can modify the life of the community"? The answer turns out to be CREFAL experts, who believe that they can make Tzintzuntzan's handicraft production more efficient. In a scene nearly identical to the one with the doctor in The Forgotten Village, the film shows the CREFAL representative walking through the village, attempting to impart his handicraft methods. The narrator claims, "He doesn't feel sad when many neighbors..." and then trails off, as we see three different house doors opening a crack, then shutting again into darkness. But whereas in Forgotten Village the door-closing scene is pivotal and serious, in Tzintzuntzan the narration is playful. "He knows some would have to be interested," the voiceover continues, cutting to a smiling white-haired man. "Here is an important villager, inclined to accept CREFAL's services. And then, since he has a lot of influence in town, not much time passes before his fellow villagers follow his example." After this scene, other villagers spill out of their homes and follow the important villager down the street in a joyous parade.

The parade, eventually, dissolves into an assembly line of artisanal pots and weavings. The narrator explains that, by partnering with the International Labor Organization to create modern weaving workshops, and with the state to give oil-burning kilns to the potters of Tzintzuntzan and two thousand other towns in Mexico, CREFAL has allowed the potters to rediscover the artistic qualities that characterized the ceramic output of their ancestors. As men work triumphantly, assembly-line style, making bricks, the narrator intones, "Nothing is impossible for men if, throwing off the weight of routine, they revive their cultural heritage, to find within it the admirable qualities of their race... Tzintzuntzan is no longer the sleeping village of times past... the inhabitants have broken definitively with the isolation to explore the world of collective labor." Thus, while the film reiterates the clichés of Forgotten Village--depicting the village as sleepy and isolated until "awakened" by experts, not allowing its subjects to speak on camera-the process of development feels slightly different. Spectatorship and enlarged desires do not really factor into the vision at the end; a parade through town that anyone can join replaces the moments of rapt spectatorship more common to the development mode.

CREFAL's films and filmstrips influenced other development organizations. In its early days, USIA looked to CREFAL for inspiration, asking for materials and producing publications about CREFAL's process for making development media. Throughout CREFAL's existence, USIA, as well as other US and European development organizations, continued to praise its work and order its films..$^{50}$ However, despite this international interest in the fundamental education model, by the early 1960 s the model and practice at Pátzcuaro was in decline. UNESCO abandoned the idea of fundamental education at its General Conference in 1958, arguing that the term "led to confusion." ${ }^{51}$ After this, CREFAL began to reorient itself around the principle of 
community development, which was gaining more currency in US and international circles. This meant the end of CREFAL's commitment to training documentary filmmakers, as well as the slow decline of its attempt to place educational screenings at the center of its development efforts. The demise of these efforts was hastened by UNESCO's 1961 decision to cut CREFAL's budget; artists there continued to experiment with filmmaking throughout the early 1960s, but mostly did not have the resources to finish their films. ${ }^{52}$ That was also the moment of both US escalation of development programming and a change in USIA filmmaking strategies, which meant that the US agency took on much of the work of selling development to the world.

\section{USIA in the 1960s: James Blue and the Success of the Formula}

By the 1960s, the years John F. Kennedy termed "the development decade," questions around the form development would take had largely been resolved. As the Kennedy administration poured money into development ventures, the United States became the center of development filmmaking, producing films dedicated to showcasing new programs, particularly the Peace Corps and the Alliance for Progress in Latin America. These films, many of which were made for television magazine programs such as CBS's The Twentieth Century, were shown in classrooms around the country. They were mostly meant to explain and advertise development projects to urban modern audiences, rather than to teach developing communities specific skills; USAID films were screened for the US Congress as well as in cities around the world to trumpet the effects of the Green Revolution and other development programs. ${ }^{53}$ Visually and thematically, these films embody the principles of Cold War modernization theory. They schematically depict villagers, aided by experts, throwing off their cultural superstitions and torpor in order to pursue freedom in the form of regimented wage labor.

31 USIA in the 1960s, while committed to a similarly rigid view of development, allowed more room for formal experimentation then either television documentary or USAID instructional film. Under the direction of Edward R. Murrow and film section leader George Stevens Jr., USIA hired talented artists such as the liberal James Blue, as well as conservative Cold Warrior Bruce Herschensohn, to depict development projects in Latin America. As Cull demonstrates, despite their ideological divergence, both produced acclaimed documentaries during the Kennedy years, with identical didactic messages and similar poetic sequences, indicating consensus across the political spectrum, and especially within USIA, about both the urgency of Cold War development interventions and what those interventions might look like..$^{54}$ At USIA, Blue developed a self-conscious style that gently mocked USIA's 1950s "progress films" and assumed a sophisticated spectator in order to make the sentimentality of development new. His films also depict the idea of development as spectatorship, attempting to imbue with joy the process of becoming a passive spectator and attaining visual order at the level of population.

Letter from Colombia is the film from Blue's 1962 "Colombia trilogy" that demonstrates the greatest self-consciousness about the development film's form. After a gauzy beginning in which the camera pans over mountains, makeshift shacks, and running children, the letter-writer narrator confesses that "I have come here to make one of those films about progress that you see from time to time.... Progress with a big P that 
you can measure in tons of bricks and miles of road." However, Blue quickly assures the viewer of the film's sincerity, using this self-conscious jibe at progress to differentiate his good-faith attempt from previous ham-fisted ones: "This is about my search for that progress, what I found, and where I looked to find it," the narrator confesses, as the film shifts to indoor space, into a room with a woman stacking and polishing coffins. "Here there was much to be done," the narrator intones, "in this land where death was accepted as a part of daily life." The film concludes by narrating an episode of a development worker teaching an old farmer an unspecified new chicken farming technique. As the camera zooms in on the farmer's wrinkled, inquisitive face, the narrator concludes: “And suddenly, a sign of progress. Not machines, nor factories, nor steam-driven turbines, but a spark of interest in an old man's eyes. The look of a student learning, you remember, when he thought there was nothing more he might learn. A kind of miracle in a chicken coop."

This equation of underdevelopment with the acceptance of death (and thus development with the avoidance of or triumph over it) is fairly common in 1960 s development films; this sharp dichotomy is sometimes expressed in terms of "living for the future," a state starkly opposed to the that of entire communities "living out their days" and "starving slowly" as underdeveloped subjects. ${ }^{55}$ The film's rejection of "progress with a capital P," in the form of "machines, nor factories, nor steam-driven turbines," signals a rejection not of those sorts of interventions (which were certainly being encouraged by the Alliance for Progress), but rather of them as compelling subjects for film treatment. Instead, Blue's film reanimates Forgotten Village's insight, arguing that inspiring personal stories of throwing over superstition could sell the Alliance's universalizing, thoroughgoing, and often violent interventions more easily than showier films about agricultural techniques or mechanization.

Blue's other two films even more strongly emphasize the human side of development interventions by representing the joys of witnessing an experiential sense of order. Evil Wind Out crafts a fictional story about a boy with a vitamin deficiency who is harmed by the village healer, shunned by his fellow townspeople, and then cured by a visiting doctor. After the boy has been healed and the town has expressed its happiness and gratitude by constructing a new health center, villagers crowd around the health center window, jostling to see the clean white equipment. School at Rincón Santo contains a similar scene, this time of villagers watching a teacher commanding her pupils to move about the newly constructed schoolhouse: one child is ordered to move to the back, another to the front, another to the other side. All do so dutifully. Throughout this senseless ordering of children's bodies, the villagers look on lovingly through the classroom windows; they continue to do so as the teacher forces the children into a seemingly endless repetition of the alphabet. These lessons, it seems, are taught and lovingly observed for the purpose of instilling order in the population; the children's bodies are regimented by the teacher, and the adults passively observe that regimentation, imaginatively identifying with the power that now regulates their children.

Blue's Colombia trilogy was celebrated by US and global spectators, winning several European film festival prizes. The films were shown at US universities and screened widely around the world; a May 1963 USIA memo reported that posts in 28 countries had ordered $32216 \mathrm{~mm}$ prints of the three films for nontheatrical showings, and 53 for theaters, and reports favorable audience reactions from audiences in Ethiopia, 
Pakistan, India, Israel, Rhodesia, and Togo. ${ }^{56}$ George Stevens Jr. boasted of a study on School at Rincón Santo involving 500 people, in which there was an $18 \%$ rise in approval of the Alliance for Progress after seeing it. ${ }^{57}$ It is not clear that the documentaries were the greatest advertisement for America on offer: Stevan Larner, Blue's collaborator at USIA, recalled in 1980 that "On my first trip to Latin America I asked the USIS people what sort of film went over best with their audiences. The answer, without exception, was The Golden Age of Comedy, a '30-minute compilation of silent-movie comic greats." Larner recalls that USIA screenings would begin with the comedy compilation and would then show "what staff members referred to as 'The Freight,' the message they wanted." ${ }^{58}$ Nonetheless, subsequent critics' attempts to see in these films a critique of development, for example Jennifer Horne's contention that the coffin scene from Letter acknowledges "the human cost of industrialization," seem difficult to support. Blue's writings, his films' sense of wonder at community self-help ventures, and audiences' positive reactions to the films all point to their complete commitment to, and successful selling of, Alliance for Progress interventions..$^{59}$

By the late 1960s, as the world began to realize the extent of the United States' disastrous modernization ventures in Vietnam, Blue began to question the US government's vision of progress and self-help he was meant to sell. His 1968 AcademyAward-nominated USIA documentary, A Few Notes on Our Food Problem, moves beyond self-reflexivity for art's sake in order to question the model that would make the underdeveloped into desiring spectators. "Statistics say," the voiceover intones, as the film opens on an undulating wheat field buzzing with swarming insects, "that the world is losing the ability to feed its growing population." "For the next thirty minutes we are going to move our camera about the earth to show you images which illustrate the problem." The fields and locusts dissolve into a flock of geese, which swells to fill the entire screen as the voiceover lists population statistics. The film's "search for images" begins, however, not with an exploration of population or agriculture but with a "wandering motion picture impresario," showing films out of his truck to an exuberant young audience on a city street in India. The film slowly winds, and then we see, from inside the truck, the children's expectant eyes peering through the peepholes. "These children, at a time when the world is not growing enough food, look beyond the images in this dark box and begin to dream of a better life. Their dreams are a force that can change the world." Taking as its starting point the child-spectators on whom The Forgotten Village, Tzintzuntzan, and Blue's early films close, A Few Notes asks what it means to create new desires and expectations in people when the economic structure and resource base to satisfy them simply does not exist.

Here Blue, like Lerner, argues for film's immense power to reorganize the subjectivities and desires of spectators. But in A Few Notes, dreams are ominous, and they only become more so when the film brings us face to face with the projector itself, surrounded by darkness, while the voiceover warns of the "billion new people who, like their parents, will expect to live better." Film itself becomes the culprit, the villain at the heart of the food and population crisis (which was, it is worth pointing out, greatly mischaracterized and exaggerated in the 1960s): having made people want a better life, now film must account for a world that cannot support their desires. The contradiction between A Few Notes' refrain of the passive construction, "It has been said that the traditional farmer, given the chance to grow more food, would not" and its interviews with farmers who disprove this formula by explaining that they cannot sell their surplus crops, indicts modernization theory and development films, including Blue's 
earlier USIA films. The villagers contradict those earlier films' repeated assertions that superstition and stubborn traditionalism hold villagers back, as well as their insistence that villagers must transform their lives without considering the consequences; in allowing them to speak at all, Blue's film constitutes a partial break with the certainties of the early Cold War. At the same time, while it perceives these particular contradictions in the development regime, the film cannot imagine a correction to that regime originating anywhere but the minds of experts; as Blue explained in a note to USIA's Washington office, "Goal of film to show farmer's perspective to influentials." 60 The child/farmer/spectator, for Blue as for Lerner, is passive, learning to identify with the shiny objects on the screen and setting off down a predictable path of amplified desire. The option of turning away from these images of a better life has by the late 1960s become unthinkable.

A Few Notes on Our Food Problem thus only partially perceives one of the key dangers of the modernization and development frameworks that dictated so much Cold War policy: experts can be, and often are, wrong. Development planners compel mass migration to cities, then decide that increasing rural production is more important; tempt farmers to abandon ancient farming methods and use pesticides, then in the next decade instruct them to take up sustainable agriculture; preach male supremacy and getting women out of the fields, then bestow gender equality on those same communities. A Few Notes sensitively explores this push and pull, capturing how nonWestern communities have been incited to desire a Western lifestyle and then informed that they are straining their resource capacity. These conflicts in development around food and population, together with the utter failure of the forced modernization projects of the Vietnam War, led to a crisis of representation for USIA: in 1970, the agency officially renounced international development as part of its mission, concluding that USIA "does not pursue 'development' as an end," and "is not responsible for pushing the development goals of other nations for them." ${ }^{61}$

As the above account indicates, the dynamic that A Few Notes' opening scene dramatizes, that of masses of film spectators being seduced into development's imperative to "live better," was never as reliable as the film's depiction of it suggests. In the 1940s The Forgotten Village, despite its producers' dreams of reaching 'underdeveloped' Mexican crowds, influenced only US experts. In the 1950s, modernization messages in US propaganda films were largely lost on representative “Third World nationals." UNESCO's interactive fundamental education project was more successful at changing hearts, minds, and farming techniques, but was soon supplanted by the better-funded and more hierarchical community development mission. The USIA development films of the 1960s, as a small part of this enormous, unilateral community development effort, built on the work begun at CREFAL, producing in the early and mid-1960s a more widespread and rigid consensus about what development looked like and how it would take place. But as Blue's questioning 1968 film indicates, this consensus, too, was short-lived; it would soon be more thoroughly disrupted and fragmented by the Marxist and anti-development visions of radical Third World filmmakers. If the voiceovers of development films were certain about the trajectories of the world and its people, their spectators were generally less so. 


\section{NOTES}

1. Examples of ambivalence toward technological progress in New Deal documentary include The Plow That Broke the Plains (dir. Pare Lorentz, 1936), The City (dir. Willard Van Dyke and Ralph Steiner, 1939), and Valley Town (Van Dyke, 1940). For a discussion of the rural focus and nostalgic pioneer impulse of New Deal art, see Barbara Melosh, Engendering Culture: Manhood and Womanhood in New Deal Public Art (Washington, DC: Smithsonian Institution Scholarly Press, 1991). 2. See Fatimah Tobing Rony, The Third Eye: Race, Cinema, and Ethnographic Spectacle (Durham: Duke University Press, 1996); Brian Hochman, Savage Preservation: The Ethnographic Origins of Modern Media Technology (Minneapolis: University of Minnesota Press, 2015).

3. Modernization theory works particularly emphasizing "development communications" include Daniel Lerner, The Passing of Traditional Society (Charlottesville; University Press of of Virginia, 1958) and Wilbur Schramm, Mass Media and National Development (Stanford: Stanford University Press, 1964). For accounts of modernization theory, see Nils Gilman, Mandarins of the Future: Modernization Theory in Cold War America (Baltimore: Johns Hopkins University Press, 2007); Michael Latham, Modernization as Ideology: American Social Science and 'Nation Building' in the Kennedy Era (Chapel Hill: University of North Carolina Press, 2000); David Ekbladh, The Great American Mission: Modernization and the Construction of an American World Order (Princeton: Princeton University Press, 2011). Specifically on the power of the village as privileged object of development interventions, see Nicole Sackley, “The Village as Cold War Site: Experts, Development, and the History of Rural Reconstruction" Journal of Global History 6 (2011):481-504, and Arturo Escobar, Encountering Development: The Making and Unmaking of the Third World (Princeton: Princeton University Press, 1995).

4. Beyond the films discussed below, these elements appear in Evil Wind Out (James Blue, 1962); Doña Julia (dir. Skip Faust, 1959); Las Montañas no Cambian (Jorge Ruiz, 1962); A Village is Waiting (Erica Anderson, 1963); The Unending Struggle, (Lee Bobker, 1965); and A Future for Ram (dir. Dr. and Mrs. Philips Foster, 1969).

5. For accounts of modernization theory see Ekbladh, The Great American Mission; Gilman, Mandarins of the Future; Latham, Modernization as Ideology.A few works do consider documentary films, though generally reading them as evidence of development ideology rather than considering the dynamics of their production or circulation: see Nick Cullather, The Hungry World: America's Cold War Battle Against Poverty in Asia (Cambridge, MA: Harvard University Press, 2010); Alyosha Goldstein, Poverty In Common: Community Action During the American Century; and Sheyda Jahanbani, “ 'Across the Ocean, Across the Tracks': Imagining Global Poverty in Cold War America," Journal of American Studies 48:4 (2014), 937-974.

6. Important "modernity thesis" works include Miriam Hansen, Babel and Babylon: Spectatorship in American Silent Film (Cambridge, MA: Harvard University Press, 1991) and Ben Singer, Melodrama and Modernity: Early Sensational Cinema and its Contexts(New York: Columbia University Press, 2001). Cold War film propaganda histories include Laura Belmonte, Selling the American Way: US Propaganda and the Cold War (Philadelphia: University of Pennsylvania Press, 2008) and Nicholas Cull, The Cold War and the United States Information Agency: American Propaganda and Public Diplomacy, 1945-1989 (Cambridge, UK: Cambridge University Press, 2008). Finally, accounts of educational documentary films that omit development include Devin Orgeron, Marsha Orgeron, and Dan Streible, eds, Learning With the Lights Off: Educational Film in the United States(Oxford: Oxford University Press, 2012); Charles R. Acland and Haidee Wasson, Useful Cinema (Durham: 
Duke University Press, 2012); Geoff Alexander, Academic Films for the Classroom: A History (Jefferson, NC: MacFarland, 2010).

7. For accounts of film in the context of European colonial modernization and development, see Peter J. Bloom, Stephan F. Miescher, and Takyiwaa Manuh, eds., Modernization as Spectacle in Africa (Bloomington: Indiana University Press 2014); James Burns "Watching Africans Watch Films: Theories of Spectatorship in British Colonial Africa," Historical Journal of Film, Radio and Television, 20.2 (2000): 197-211; Scott Anthony and James G. Mansell,eds, The Projection of Britain: A History of the GPO Film Unit (London: Palgrave Macmillan, 2011); Colin MacCabe and Lee Grieveson, eds., Film and The End of Empire (London: Palgrave Macmillan, 2011). Grieveson's recent Cinema and the Wealth of Nations: Media, Capital, and the Liberal World System (Berkeley: University of California Press, 2018) traces the intertwined rise of industrial cinema and the establishment of liberal global capitalism, mapping the rise and influence of important precursors to those discussed here. Seth Fein's work on Mexico is one exception to the lack of interest in film and US-backed modernization and development in Latin America, particularly his "Everyday Forms of Transnational Collaboration: US Film Propaganda in Cold War Mexico," in Emily Rosenberg, et. al., eds., Close Encounters of Empire: Writing the Cultural History of US-Latin American Relations (Durham: Duke University Press, 1998) 400-450.

8. Lerner, Passing of Traditional Society, 43.

9. Ibid., 49.

10. Ibid., 54 .

11. Ibid., 51.

12. Walt Whitman Rostow, The Stages of Economic Growth: A Noncommunist Manifesto (Cambridge, UK: Cambridge University Press, 1960) 20.

13. Jay Parini, John Steinbeck; A Biography (New York: Henry Holt \& Co., 1995) 298.

14. Ejidos are the areas of communal land historically shared by indigenous Mexicans, which were usurped by the government in the 1850s and then re-allocated to peasants in the 1917 Revolutionary land reforms.

15. Steinbeck, Letter to Herbert Kline, N.D. (c. March 1940), John Steinbeck Personal Papers, Box M1350, Folder 1, Stanford University Archives, Palo Alto CA.

16. Steinbeck, Letter to Herbert Kline, N.D. (c. June 1940), John Steinbeck Personal Papers, Box M1350, Folder 1, Stanford University, Palo Alto CA.

17. Steinbeck, A Life in Letters (New York: Viking, 1975) 208

18. Steinbeck, Letter to Herbert Kline, N.D. ("Wednesday," c. late summer 1940) John Steinbeck personal papers, Box M1350, Folder 1, Stanford University, Palo Alto CA.

19. Herbert Kline, “On John Steinbeck,” Steinbeck Quarterly (Summer 1971), 80-88.

20. Ibid, 85.

21. Herbert Kline, "Down Mexico Way: Report from a Documentary Unit Now Filming Below the Border" New York Times (21 July 1941).

22. John Steinbeck, A Life in Letters, 185-8.

23. Steinbeck, The Forgotten Village (New York: Viking, 1941), 1.

24. Philip K. Scheuer, “A Town Called Hollywood” Los Angeles Times (9 February 1941). See also Bosley Crowther, "The Forgotten Village," New York Times (19 November 1941). "Cinema," Time (8 December 1941); Paul Speegle, “'The Forgotten Village' is a Sincere Achievement," San Francisco Chronicle (16 February 1992).

25. Archer Winstein, "The Seventeen and One Half Best Pictures of 1941," New York Post (18 December 1941); “Kane Selected as Year's Best," Hollywood Reporter (22 December 1941)

26. James Ferguson, The Anti-Politics Machine: Development, Depolitization and Bureaucratic Culture in Lesotho (Minneapolis: University of Minnesota Press, 1994); Zoe Druick, "Visualising the World: The British Documentary at UNESCO," Anthony and Mansell, The Projection of Britain, 272-280. 
27. Robert Redfield, “The Forgotten Village," American Sociological Review 7.1(February 1942) 131-2; see Nicole Sackley, "Cosmopolitanism and the Uses of Tradition: Robert Redfield and Alternative Visions of Modernization During the Cold War," Modern Intellectual History 9.3 (2012): 265-95.

28. "The disputed 'Village' Letter to the editor by Alvin Johnson," New York Times (12 October 1941); Steinbeck: A Life in Letters, 235.

29. Francisco Castillo Nájera to Arthur Mayer, 13 September 1941; John Steinbeck Personal Papers, Box M1350, Folder 10, Stanford University, Palo Alto CA.

30. Norman D. Humphrey, “The Generic Folk Culture of Mexico," Rural Sociology 8 (1943), 372.

31. Mariam Colón Pizarro, "Poetic Pragmatism: The Puerto Rican Division of Community Education (DIVEDCO) and the Politics of Cultural Production, 1949-1968(Unpublished PhD dissertation, University of Michigan, 2011) 263.

32. Fernando de Moral Gonzalez, Cine Documental en Pátzcuaro (Mexico: Centro de Cooperación Regional para la Educación, 2007), 31.

33. "Evaluation of USIS-Thailand Motion Picture Activities" (March 12, 1954), 75-6 USIA Microfilm Files, 1954, Folder 34, Roosevelt Study Centre (RSC), Middelburg, Netherlands.

34. "Productivity: Key to Plenty: Pre-release Evaluations," (May 31 1954) 1, USIA Microfilm Files, 1954 Folder 34, Roosevelt Study Centre, Middleburg, Netherlands.

35. Ibid., 37.

36. Harold Orleans, "Preview film evaluation of 'A Nation Sets its course"' (15 Oct 1953) 24, Microfilm Papers of the Institute for Research in Human Relations, Roosevelt Study Centre, Middleburg, Netherlands.

37. Other negative reactions in screenings 1950s USIA films Prerelease Film Eval No. 2: "Visiting Good Neighbors" (USIA Files, Folder 29); Prerelease Film Eval No. 3: "The Hoja Takes a Wife" USIA Folder 31, Microfilm Collections, Roosevelt Study Center, Middelburg, Netherlands.

38. Joseph Watras "The New Education Fellowship and UNESCO's Programme of Fundamental Education," Paedagogica Historica, 47:1-2 (2011), 194.

39. Watras, "UNESCO's Program of Education, 1946-1959, History of Education 39.2 (2010) 219-237, and "New Education Fellowship," 201.

40. Watras "New Education Fellowship,"199.

41. See Molly Geidel, Peace Corps Fantasies: How Development Shaped the Global Sixties (Minneapolis: University of Minnesota Press, 2015).

42. "Sintesis de las actividades de la division audiovisual del CREFAL" (1953) Apoyo Técnico, folder 40-470/1953/c-5/e-2, and "Proposición de un Plan Coordinado de Producción de Materiales," (Aug 1955) Apoyo Técnico, Programa del Cine, Folder 40-45/1955/ Archivo de CREFAL, Pátzcuaro, Mexico.

43. Richard Kent Jones to Lucas Ortiz, Dec 6 1955, Apoyo Técnico, Departmento del Cine, Peliculas, y Narraciones, Folder 40-455/1955/C-8/E-3, CREFAL.

44. "Comentario Sobre Las Siguientes Peliculas," N/D, Apoyo Técnico, Departmento del Cine, Peliculas, y Narraciones, Folder 40-455/1955/C-8/E-3, CREFAL.

45. "Rama de Producción, Selección de Peliculas," Apoyo Técnico 4-21/ 1952/C-3/E-7, CREFAL

46. "Unos Sugerencias Sobre la Producción, Uso, y Evaluación de los Materiales Audiovisuales Durante la Segunda Época" Folder 40-455/1955/C-8/E-3, CREFAL.

47. H.G. Ogden,"Training in Audio-Visual Materials," (CREFAL, 1957) 12, Apoyo Técnico 43.451/1957/C-10-/E1, CREFAL.

48. J. Ernesto Rosales Urbino, untitled report, CREFAL (Aug 22 1953), Apoyo Técnico, folder 40-470/1953/c-5/e-2, CREFAL.

49. Ibid.

50. Ross McLean to Julio Castro, (Dec 23, 1953) Apoyo Técnico, folder 40-470/1953/c-5/e-2, CREFAL.

51. Watras, "New Education Fellowship," 203. 
52. Lloyd H. Hughes, “Crefal: Training Centre for Community Development for Latin America" International Review of Education / Internationale Zeitschrift für Erziehungswissenschaft / Revue Internationale de l'Education 9. 2 (1963), 226-235; Fernando de Moral Gonzales, Cine Documental en Pátzcuaro, (Mexico: Centro de Cooperación Regional para la Educación de Adultos en América Latina y el Caribe, 2007) 72.

53. The Green Revolution was a program of rapid transformation in agricultural practices in the 1950s and 1960s involving the introduction of pesticides, fertilizers, and high-yield crops. Although most commonly associated with India, it has its roots in the Rockefeller and Ford Foundations' experiments in Mexico in the 1940s and 1950s.

54. Nicholas Cull, "Auteurs of Ideology: USIA Documentary Film Propaganda in the Kennedy Era as Seen in Bruce Herschensohn's 'The Five Cities of June; (1963) and James Blue's 'The March' (1964)," Film History 10.3 (1998) 295-310.

55. Other films that explicitly voice this distinction include So that Men are Free (dir. Van Dyke, 1962); Unending Struggle, (dir. Lee Bobker, 1965); my argument here is that it also comes to be legible visually.

56. Jim Wood to James Blue (July 21 1963), box 82,fFolder 82, James Blue Personal Papers, University of Oregon, Eugene, Oregon.

57. George Stevens, "Remarks to American Film Festival Luncheon, April 22, 1965," box, 6 folder 49, 7James Blue Personal Papers, University of Oregon, Eugene, Oregon.

58. Stevan Larner, "Remembering James Blue,"in John Minkowsky, ed., James Blue: Scripts and Interviews (Houston: Rice University/SWAMP, 2002) 7.

59. Jennifer Horne, "Experiments in Propaganda: Reintroducing James Blue's Colombian Trilogy," The Moving Image 9.1 (Spring 2009), 193.

60. James Blue Notebook, 1967, box 11, folder 58, James Blue Personal Papers; James Blue Memo to Bob Butler, USIA Washington (Jan 20,1967), box 6 , folder 14, James Blue Personal Papers, University of Oregon, Eugene, Oregon.

61. Michael P. Canning, letter to USIA staff (Nov 1970) p. 2, USIA Motion Picture Division Files, 1970, National Archives and Records Administration, College Park, Maryland.

\section{ABSTRACTS}

This article tracks how mid- $20^{\text {th }}$ century US and Latin American documentary filmmakers created a visual and narrative repertoire that encouraged spectators worldwide to imagine a global transformation from the stagnant living death of underdevelopment to striving, productive lifein-development. It explores how development institutions, theorists, and filmmakers made connections between the experience of spectatorship and the odd mixture of passivity and striving that constituted the ideal "developing" subject. However, it attends not only to the ideal spectators these films attempted to create, but also to the experiences of spectators themselves, concluding that audience reactions to development films, particularly among non-experts, were often skeptical of the universal modernization trajectories on which the films insisted. 
INDEX

Keywords: Modernization, documentary, UNESCO, USIA, James Blue, John Steinbeck

\section{AUTHOR}

\section{MOLLY GEIDEL}

Molly Geidel is a lecturer in American cultural history at the University of Manchester. Her book Peace Corps Fantasies: How Development Shaped the Global Sixties, published by University of Minnesota Press in 2015, is a cultural history of the 1960s Peace Corps and its connection to the radical social movements of that decade. She is working on a history of the development film in the Americas. 